\title{
AQUATIC BIOINDICATOR - POTENTIAL MARINE MICROINVERTEBRATES AS BIOINDICATOR IN ASSESSING MARINE ENVIRONMENTAL HEALTH
}

\author{
Regina Leong, Zhi Ling and Teo, SweeSen*
}

Department of Applied Sciences, UCSI University, No.1 Jalan Menara Gading, UCSI Heights, 56000 Cheras, Kuala Lumpur, W. P. Kuala Lumpur, Malaysia

*Corresponding Author: Teo, SweeSen, Department of Applied Sciences, UCSI University, No.1 Jalan Menara Gading, UCSI Heights, 56000 Cheras, Kuala Lumpur, W. P. Kuala Lumpur, Malaysia. Tel: Tel: +603-91018880.

E-mail: teoss@ucsiuniversity.edu.my

\begin{abstract}
Aquatic ecosystems have the highest biodiversity as they support various species of organisms and provide essential environmental functions to both marine life and human society. Rapid development and urbanization contribute disturbances to both terrestrial and aquatic environment from mudflat to seabed, deep sea to coastal areas and wetlands. Health of aquatic ecosystems deteriorates when the ecosystems unbearable to the environment stressors especially from anthropogenic activities. Therefore, proper water quality management was essential for aquatic ecosystems to enhance the performances. Marine macroinvertebrates suggested to be the ideal marine bioindicators for monitoring and assessing aquatic ecosystems by providing health status information and identifying the sources of marine pollutions. This review paper discusses potential of sea cucumber as marine bioindicators in reducing heavy metals, organic loads and balancing the physiochemical parameters. The optimum physiochemical parameters for survival of sea cucumbers are water temperature of $29^{\circ} \mathrm{C}$ to $33^{\circ} \mathrm{C}$, salinity of 28 to $33 p p t$, water $\mathrm{pH}$ of 7.5 to 8.2, water transparency of 25 to $100 \%$ and DO level of 6 to $8 \mathrm{ppm}$. Researches proved that sea cucumbers had the capability to decline pollutants and excess nutrients as they can absorb nutrients and organic waste in the sediment, nutrient recycling, bioturbation and balance the water $\mathrm{pH}$ in the aquatic ecosystems. Hence, well-established water environment was built for survival of sea cucumber (Holothuria leucospilota) in the preliminary study with $26.1^{\circ} \mathrm{C}$ to $26.8^{\circ} \mathrm{C}$ water temperature, 7.7 to 8.2ppm DO level, 29 to 30ppt salinity and $100 \%$ water transparency. It is believed that marine macroinvertebrates are the most ideal serve as bioindicators in assessing ecosystem health.
\end{abstract}

Keywords: macroinvertebrates; bioindicator; water quality; pollution; sea cucumber 


\section{Introduction}

Marine ecosystems cover $71 \%$ of earth surface which are the largest aquatic ecosystems from deep oceans to coastal reefs ecosystem, mudflat to sea grass beds. Marine ecosystems provide essential services to all living organisms. These systems are the most diverse as they support variety of marine life within this ocean. Marine ecosystems can be divided into four zones which are intertidal, pelagic, benthic and abyssal (Figure 1). Intertidal zone is the marine shoreline where the ocean meets the land. This area is exposed to air during low tide and covered with seawater during high tide. Tendency of living organisms inhabit in the zone varied and often more diverse due to large temperature fluctuations, wave action, and prolonged to air exposure. Pelagic zone comprises of water column of open sea. Variety of fish, aquatic plants and larger mammal were found inhabit in the zone, yet the number of species found decreased as going down the ocean due to nutrients abundance, dissolved oxygen (DO), availability of sunlight, water temperature and salinity (Augustyn et al., 2020). Benthic and abyssal are the deepest regions of the ocean. Marine organisms in these regions are able to tolerant to cold temperature, extreme pressures and darkness. Hence, marine organisms in benthic and abyssal zones are specific and mostly are invertebrates. However, these zones are important as they play vital role in the ecosystem health where benthic organisms serve as crucial role in playing bioindicators of water quality (Kingsford, 2018; Gresens, Smith, Sutton-Grier and Kenney, 2009).

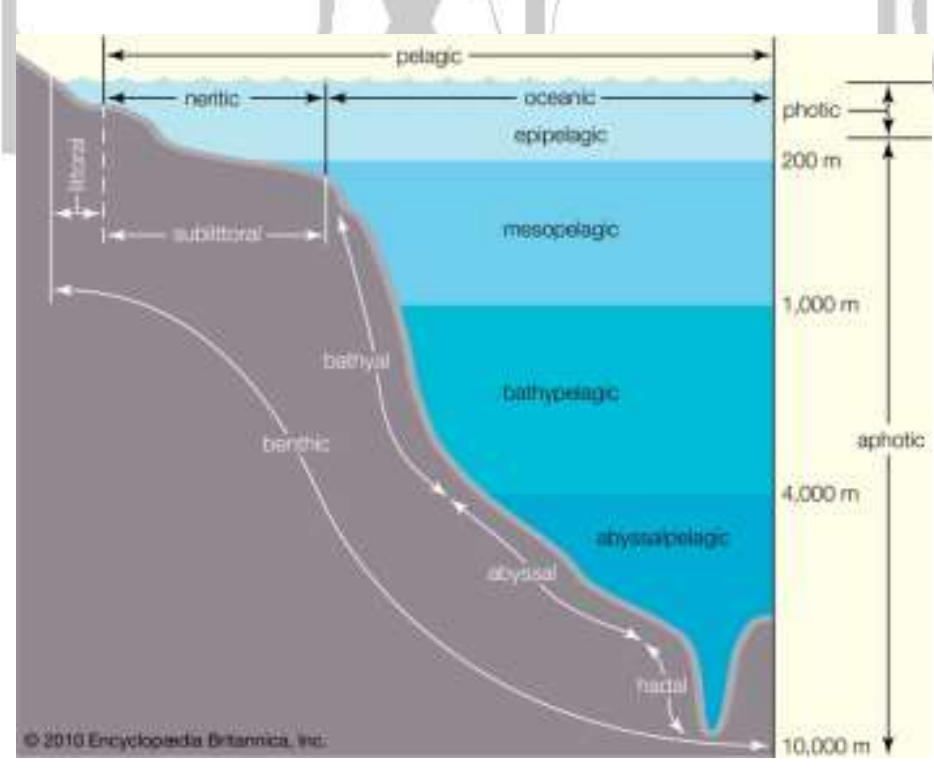

Figure 1: Zonation of the ocean (Kingsford, 2018).

\section{Marine Bioindicators}

In these recent years, marine pollution has become major concerns due to rapid urbanization and industrialization
(Gasim et al., 2013). The impact of marine pollution mostly felt in estuary and coastal areas as the contaminants flow through these regions towards open sea. 
Pollutants affecting marine environments are in wide range including heavy metals, organic chemicals, toxins, plastics, pathogenic species, sewage and municipal waste. These contaminants can be bioaccumulated and biomagnified in the food chain from plankton to human beings which pose negative impacts to both aquatic organisms and human society. Hence, marine bioindicators play vital role in monitoring and assessing the sources as well as agents in contributing to the pollutions. Bioindicator is a living organism such as plankton, plants, animals and microbes that provides information of the health of a natural ecosystem (Parmar, Rawtani and Agrawal, 2016). It assesses environment quality, biogeographic changes and trends over time including anthropogenic and natural stressors that deteriorates the water quality.

Bioindicators are used to indicate positive or negative effects of natural environmental changes of particular region. They have been widely used to detect environment changes contributed by pollutants that affecting the species biodiversity. This is because bioindicators can indicate the environment condition with their environmental tolerance. For instance, species with narrow tolerances are sensitive which showed their biotic response towards pollutants and environmental changes. However, species with high tolerance are less sensitive towards environmental changes indirectly the affecting the entire community of that particular region (Holt and Miller, 2010). Bioindicators can be categorized into four categories with different purposes; pollution, environmental, biodiversity and ecological (Figure 2). Pollution bioindicators are utilized to detect presence of pollutants whereas environmental bioindicators are used for monitoring environmental changes in the area. Biodiversity bioindicator can detect changes in species biodiversity while ecological bioindicators are utilized to detect changes in natural surroundings and their impacts. There are several types of bioindicators can be utilized into these categories include plants, animals, macroinvertebrates and microbial indicators.

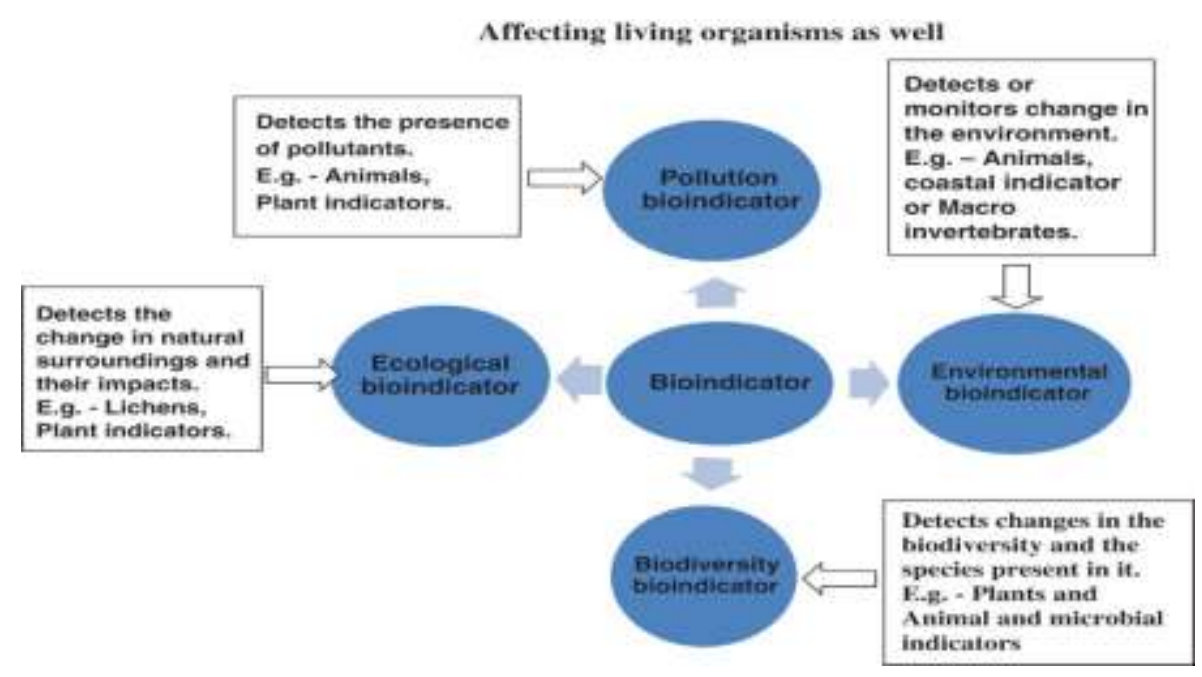

Figure 2: Types of Bioindicators (Parmar, Rawtani and Agrawal, 2016). 


\section{a. Plant/algae indicator}

Plants are sessile and sensitive towards recognition of surrounding environmental changes. They showed morphological changes and disappearance of species towards pollutants (A Majid, Ramli and Chia Phang, 2015). When the environmental components for plants survival such as temperature, soil moisture, nutrients and air pollutants exceeded the range for survival of plants, the plants showed signs and symptoms of abnormal growth (Nouchi, 2002). The appearance changes of the plants are the important indicator to environmental pollution. For instance, excessive nutrients or chemicals as well as heavy metals present in the soil limiting the growth of plant and indirectly, they accumulate the chemicals or heavy metals from the roots to the leaves which can affect organisms in higher trophic level that ingest the plants. Macrophytes such as seaweed can also provide valuable data for marine ecosystems health due to their characteristics that quickly achieve equilibrium with their natural surrounding and sessile in one place. Seaweed act as an important role as bioindicator in monitoring marine pollution as they are sensitive to pollution. Seaweed is sessile in the water which used to monitor one location over time due to its absorption ability of metal ions present in the environment (DadolahiSohrab et al., 2011). Algae can also be a good bioindicator in monitoring environment health. Excessive nutrients such as nitrogen and phosphorus can cause eutrophication where algal bloom occurs indicated the ecosystem is unstable and poor water quality.

\section{b. Animal/Macroinvertebrate indicator}

Changes in animal population may indicated pollution or stress happens damaging the ecosystem. Animals are dependent on food sources, hence when the food sources depleted, the number of animal populations will be affected. This affects the whole food chain from lower level to higher level tropics. Thus, changes in populations indicated adverse impacts to the ecosystem. Animal indicators can also aid in detecting toxic metals in animal tissues as they capable in bioaccumulation and biomagnification from environment sources ingested (Stankovic and Stankovic, 2013). Polluted or unstable environment can cause physiological and behavior changes or deformities in animals. Fish were often used as bioindicators for aquatic monitoring assessment as they are sensitive to pollutants as well as show symptoms and signs when the environment was in abnormal condition. Excessive nutrients, poor water quality and depletion DO affect the survival of fish and diversity (Naigaga et al., 2011). Histological examination and morphological test can used to detect tissues condition and signs that showed fish disease due to pollutants (Chovanec, Hofer and Schiemer, 2003).

Other than that, macroinvertebrates also one of the popular bioindicators for aquatic monitoring assessment. They are powerful and reliable indicators in aquatic ecosystem health as most of them are benthos which live at the bottom of water bodies, spend most of lives in water and extremely sensitivity towards contaminants. In addition, they 2020 November Edition | www.jbino.com | Innovative Association 
have limited mobility which they are mostly expose to contaminants and have the capability in integrate stressors effect they have been exposed. Some of the macroinvertebrates for bioindicators are molluscs, crustaceans and echinoderms. Blue mussel had been used since 1986 for monitoring metal pollution because bivalves are good indicators in heavy metal accumulation as they are sessile at one location and accumulate contaminants in its tissues which can be determined by molecular diagnostics (Mariné Oliveira, do Couto, de Freitas Lima and do Bomfim, 2016). Therefore, macroinvertebrates as biodiversity, ecological and environmental indicators help to detects the undesirable changes of environment and identify the sources of pollution that deteriorates the water quality.

\section{c. Microbial indicator}

Microorganisms are frequently used as indicators for natural ecosystems as they are abundance and easily being tested. According to Manickavasagam et al (2019), some microorganisms develop stress proteins when exposed to pollutants such as Cadmium and Benzene. This scenario can be used as signals for the ecosystem that had been polluted. Microbial indicators are also often used for water quality testing as microorganisms present as important part in the oceanic biomass and responsible for biogeochemical cycles as well as biological processes (Parmar, Rawtani and Agrawal, 2016). The growth of microorganisms is fast, and they can react to pollutants present in the water column and in the sediment showing physiochemical changes for instance, the water become turbid, level of $\mathrm{DO}$ and $\mathrm{pH}$ level changes. Some microorganisms have been used as biomarkers for examination of environmental pollutions where they will show adverse condition in molecular ways as they may undergo mutagenesis and respond to environment changes (Vallaeys, 2017). Hence, the DNA-based molecular information from microbial indicator can be used for environmental monitoring purposes.

\section{Sea Cucumber as Marine Bioindicators}

In marine environment, macroinvertebrate communities often being used as environmental, ecological, and biodiversity indicators worldwide to assess ecological health. Sea cucumber have been proposed as ideal bioindicators for monitoring contaminants especially sedimentation, nutrient inputs and heavy metals under chronic exposure. This is due to marine invertebrates have the ability to indicate various anthropogenic stressors that caused poor water quality of marine environment (Patrick, Mbuebue and Nadine, 2015; Pawhestria, Hidaya and Putro, 2015). Sea cucumbers are echinoderms from class Holothuroidea. It is a soft-bodied invertebrate with a leathery skin and elongated body containing single, branched gonad. Sea cucumber mostly found in the deep seafloor and tropical shallow-water coral reefs. They have been a popular luxury seafood in Asian and has been introduced into commercially cultivated in aquaculture systems due to its demand for human consumption. They also recognized as a tonic and traditional remedy in medical benefits against 
hypertension, asthma, constipation, rheumatism and impotence in Japan, China and Malaysia (Hu et al., 2010).

Sea cucumbers are ideal as marine bioindicators as they provided characteristics of a bio-indicator such as worldwide distribution, long survival, easily collect, abundance and capability in heavy metals accumulation. They are also deposit feeders or scavengers that feed on plankton and debris in the benthic zone using their tube feet. Therefore, sea cucumbers play an important ecological role in nutrient recycling and bioturbation as they can swallow sediments and extract organic matter as they pass through the gut as well as able to overturn and rework the sediment layers which increased the permeability. Besides, they can serve to clean the seabed, balance the seawater $\mathrm{pH}$ by increasing alkalinity and act as food sources to higher trophic level in marine food webs.

In sea cucumbers, it is found that they detect permanent marine ecological stress and long-term biological impact as they could accumulate heavy metals and reduce excessive nutrients present in the water and sediment. Heavy metals are toxic, permanent, nonbiodegradable and can be accumulated in the food chain. Bioaccumulation of contaminants can be detected by body components of sea cucumbers such as body wall, gut and haemal system. Sea cucumbers have good digestive system where they digest the organic matter as they pass through the guts and secrete calcium carbonate and ammonia in the form of by-products. These elements act as primary ingredients for coral formation and fertilizer to promote coral growth. Sea cucumbers have the ability to remove Cadmium $(\mathrm{Cd})$, Lead $(\mathrm{Pb})$, Zinc $(\mathrm{Zn})$, Copper (Cu) and Manganese ( $\mathrm{Mn}$ ) in the water. $\mathrm{Pb}$ cations have high affinity for calcic skeletons and are heavily concentrated in the body wall (Ahmed, Mohammad Ali and Bat, 2017). Bioaccumulation of heavy metals in tissues of sea cucumbers obstructed antioxidant defense system in the animals (Mohamed and Aml, 2017). However, no general bioaccumulation pattern of heavy metals in sea cucumber was further studied. The bioaccumulation of trace metal in the sea cucumber was not exceed the maximum allowable legal limit and considered still safe for human consumption. (Jinadasa, Samanthi, and Wicramsinghe, 2014). Sea cucumber are more sensitive to heavy metals such as copper ions. According to Li et al. (2016), copper ions $\left(\mathrm{Cu}^{2+}\right)$ in the water can cause metabolic changes and physiological changes in the organisms such as evisceration when exceeding normal levels (1 $\mathrm{mg} / \mathrm{L}$ ). The maximum allowable copper ions in the sea cucumber causing no harm was $0.007 \mathrm{mg} / \mathrm{L}$ (Li, Tian, Yu and Dong, 2016). 
Rapid development in Malaysia contributed more wastes ended up in the natural water bodies especially marine ecosystem. Marine ecosystem in Malaysia showed sign of pollution due to anthropogenic activities that caused industrial and domestic wastes contaminated the water bodies. Preliminary study aims to establish an ideal environment for marine invertebrates (sea cucumber) in order to perform its ecological role. The potential of using marine invertebrates in reducing pollution in marine water will be highly discussed for further monitoring

\section{Discussion}

A research project has been studied using sea cucumber (Holothuria polii) as bioindicator by assess the biological effect of marine pollution. H. polii were collected from two stations; Abo-qir (industrial site) and Miami (reference site) to study their antioxidant defense responses towards marine pollutions using oxidative stress biomarkers, heavy metal bioaccumulation and Rickettsia-like organism (RLOS) infection. According to Mohamed and Aml (2017), the result of $H$. polii that were exposed to pollutants in each station showed significant reduction in antioxidant parameters, accumulation of heavy metals in body compartments and infection of RLOs in their digestive and respiratory system. These adverse condition of $H$. polii were impacted by the presence of anthropogenic pollutants in each station especially in the industrial site as more contaminants produced from the industrial site.

\section{Bioaccumulation of Metal Ions}

Heavy metal accumulation was one of the vital environmental pollution which affects both aquatic organisms and human society as heavy metals is persistent. Excessive heavy metals impact on organisms' molecular activities including DNA damage, cellular metabolism and organelles functions (Tchounwou, Yedjou, Patlolla and Sutton, 2012). Heavy metal concentrations of water samples in two study stations; AboQir and Miami showed significant increase in trace metals including $\mathrm{Zn}, \mathrm{Mn}$, $\mathrm{Pb}, \mathrm{Cu}$ and $\mathrm{Cd}$. The results in Table 1 showed that heavy metals concentration was higher in water samples from industrial site (Abo-Qir) than that of reference site (Miami). Besides, the accumulation of heavy metals concentration in tissue samples of $\mathrm{H}$. polii obtained increasing concentration from Abo-Qir industrial site compared to Miami reference site. This is because heavy metals discharged from the chemicalintensive industries especially electronic industry which commonly ended up flow into the water bodies. Once the metal ions enter the water bodies, they are persistent in the water column and can be bioaccumulated by aquatic organisms as well as human community. These metal ions can result in serious health effects including reduced growth and development, cell damage, deformities as well as impairment of autoimmunity (Barakat, 2011). Consequently, bioaccumulation of heavy metals in $\mathrm{H}$. polii impaired its antioxidant deference response leading to oxidative stress which influence its ability to defense from environmental stress and predators (Hu, 2000). 
Table 1: Concentration of heavy metals in tissue and in water in both industrial and reference sites (Mohamed and Aml, 2017).

\begin{tabular}{|c|c|c|c|c|c|c|}
\hline & & Wintel & & & Summe & \\
\hline & Abo-Qir & Miami & p & Abo-Qir & Miami & $\mathbf{p}$ \\
\hline Hea & in tissue & $/ \mathbf{k g})$ & & & & \\
\hline $\mathbf{Z n}$ & $4.6 \pm 0.2$ & $4.3^{@} \pm 0.2$ & $0.008 *$ & $5.0 \pm 0.2$ & $4.6^{@} \pm 0.2$ & $0.003 *$ \\
\hline Mn & $6.2 \pm 0.4$ & $4.2^{@} \pm 0.3$ & $<0.001^{*}$ & $6.4 \pm 0.3$ & $5^{\circledR} \pm 0.4$ & $<0.001 *$ \\
\hline $\mathbf{P b}$ & $1.9 \pm 0.1$ & $0.6^{\Theta} \pm 0$ & $<0.001^{*}$ & $1.9 \pm 0.1$ & $1^{\varrho} \pm 0.2$ & $<0.001^{*}$ \\
\hline $\mathbf{C u}$ & $2.7 \pm 0.4$ & $2.4 \pm 0.2$ & 0.063 & $2.9 \pm 0.2$ & $2.6 \pm 0.2$ & 0.059 \\
\hline Cd & $1.2 \pm 0.2$ & $0.9^{@} \pm 0.1$ & $0.018^{*}$ & $1.3 \pm 0.2$ & $1^{\varrho} \pm 0.1$ & $0.005^{*}$ \\
\hline Hea & in water & $/ \mathrm{L})$ & & & & \\
\hline $\mathbf{Z n}$ & $5.2 \pm 0.2$ & $4.8^{@} \pm 0.1$ & $0.009 *$ & $5.4 \pm 0.3$ & $5^{\varrho} \pm 0.2$ & $0.017 *$ \\
\hline$\overline{M n}$ & $4.4 \pm 0.2$ & $2.6^{@} \pm 0.2$ & $<0.001^{*}$ & $4.2 \pm 0.3$ & $3^{(} \pm 0.2$ & $<0.001^{*}$ \\
\hline $\mathbf{P b}$ & $2.2 \pm 0.2$ & $1.1^{@} \pm 0.2$ & $<0.001^{*}$ & $2.4 \pm 0.2$ & $1.3^{@} \pm 0.2$ & $<0.001^{*}$ \\
\hline $\mathbf{C u}$ & $1.9 \pm 0.1$ & $1.2^{@} \pm 0.2$ & $<0.001 *$ & $1.9 \pm 0.1$ & $1.3^{@} \pm 0.2$ & $<0.001^{*}$ \\
\hline Cd & $1.2 \pm 0.2$ & $.9{ }^{\circledR} \pm$ & $0.003 *$ & $1.3 \pm 0.2$ & $1^{\Theta} \pm 0.1$ & $0.008 *$ \\
\hline
\end{tabular}

$\mathrm{p}$ is the $\mathrm{p}$ value for t-test for comparing between the two locations in each season.

${ }^{\circledR}$ : Statistically significant between the two locations in each season.

*: Statistically significant at $\mathrm{p} \leq 0.05$

A study conducted by Lin et al., (2018), proved heavy metal concentrations ( $\mathrm{Zn}$, $\mathrm{Mn}, \mathrm{Cu}, \mathrm{Hg}, \mathrm{As}, \mathrm{Pb}, \mathrm{Cd}$ and $\mathrm{Cr}$ ) bioaccumulated in the body compartments of all tested sea cucumbers (Acaudina leucoprocta) that inhabit in sea mud (Table 2). It was concluded that the amount of heavy metals accumulated in the body wall of A. leucoprocta directly proportional to the weight and size (Figure 3). This indicated the concentration of heavy metals tend to increase gradually as $A$. leucoprocta continue to growth as they scavenge sediments and more food sources intake when the size is bigger. Once they enter the food chain, the heavy metals can be bioaccumulated and biomagnified in the aquatic organisms as well as human community which can cause serious health disorder. 


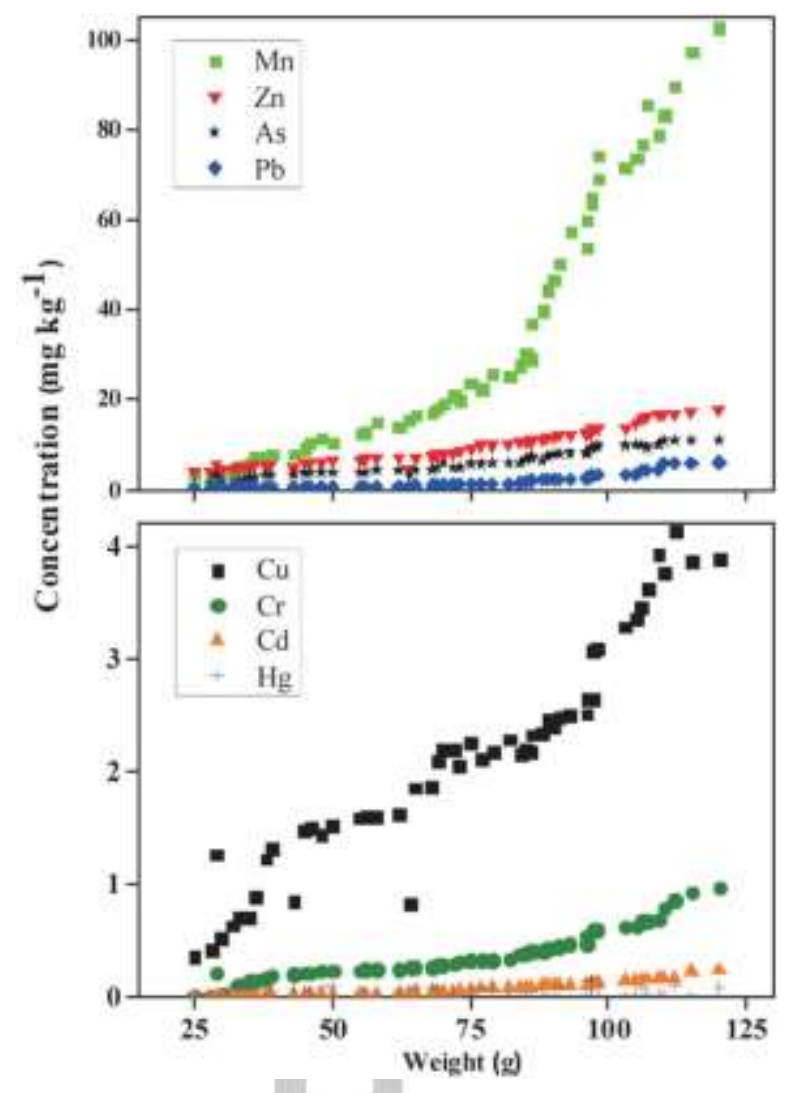

Figure 3: Heavy metal concentrations bioaccumulated in the body wall with different weight of $A$. leucoprocta (Lin et al., 2018).

Table 2: Trace metals concentrations in different body compartments of A. leucoprocta (Lin et al., 2018).

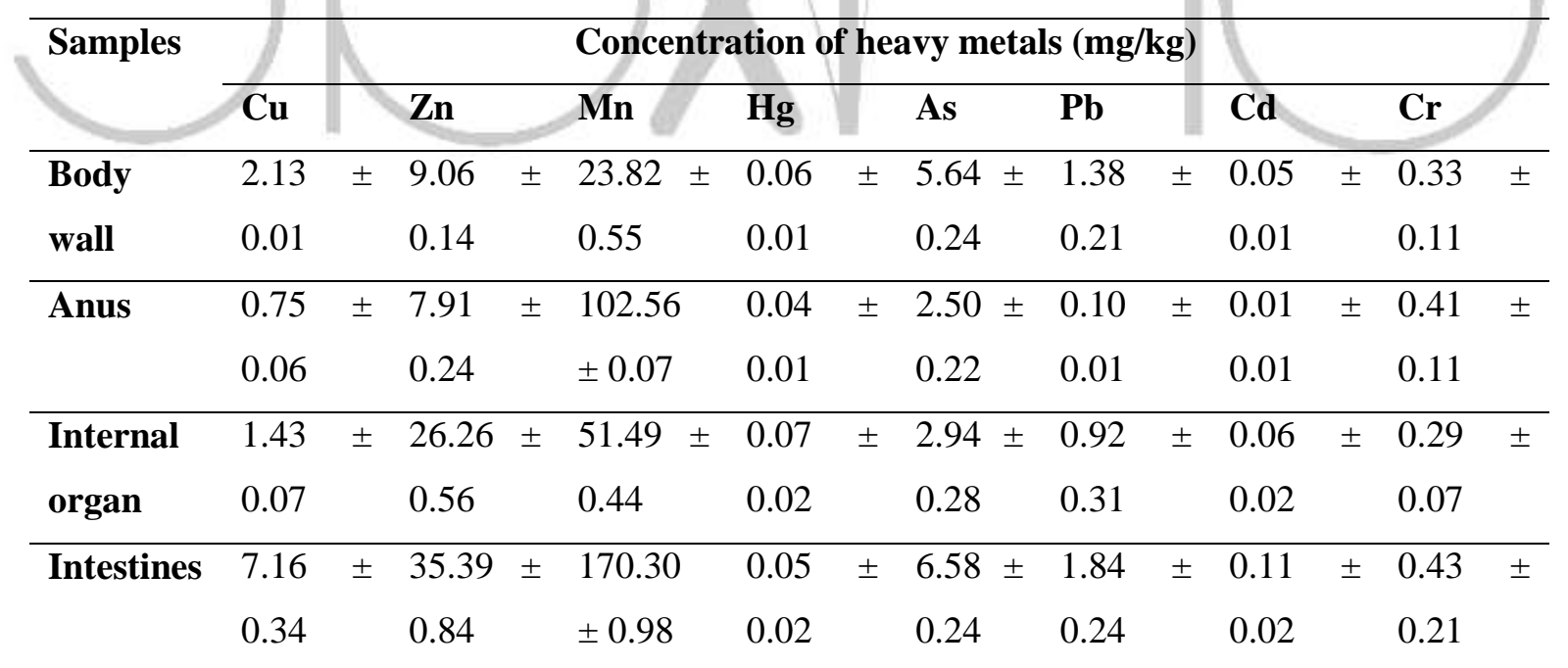

Based on the results (Table 2), the levels of heavy metals (Cu, $\mathrm{Zn}, \mathrm{Hg}, \mathrm{Cd}$ and $\mathrm{Cr}$ ) were lower than the maximum residue limits (MRLs) allowed in food legislation which were $50 \mathrm{mg} / \mathrm{kg}, 30 \mathrm{mg} / \mathrm{kg}, 0.5$ $\mathrm{mg} / \mathrm{kg}, 0.5 \mathrm{mg} / \mathrm{kg}$ and $0.5 \mathrm{mg} / \mathrm{kg}$ respectively. However, As (>0.5 mg/kg) and $\mathrm{Pb} \quad(>0.5 \mathrm{mg} / \mathrm{kg})$ levels were exceeded the limit of maximum residues

permitted. Concentrations of heavy metals were heavily accumulated in body wall and intestines especially As (5.64 $\pm 0.24,6.58 \pm 0.24)$ and $\mathrm{Pb}(1.38 \pm$ $0.21,1.84 \pm 0.24)$ that exceeded the limits 
(Mohammadizadeh et al., 2016). This is due to both of these compartments direct contacted with the sediments that presence of heavy metals by feeding or buried themselves in the sediments and their body wall is vulnerable to accumulate and absorption metal ions (Lin et al., 2018). This information proven that benthos has the potential as bioindicator in reducing the amount of heavy metals in water column and within the sediments (Ahmed, Mohammad Ali and Bat, 2017).

\section{Reduction Physiochemical parameters}

Sea cucumber is a scavenger that ingest sediments, feed on detritus and associated microorganisms. They are suitable as bioindicator in monitoring environmental water quality as optimum environment conditions required for their survival. Changes in water quality parameters including salinity, water temperature, $\mathrm{pH}$, water transparency and DO level can affect their growth, metabolism and physiological performance (Gunay et al., 2015; Yang et al., 2005; Dong et al., 2005). The optimum water quality parameters were shown in Table 3.

Table 3: Water quality parameters for survival of sea cucumbers (FAO, 2008; Sembiring et al., 2019; Andriyono et al., 2016).

\begin{tabular}{ll}
\hline Water Quality Parameters & Concentration \\
\hline Water temperature & $29^{\circ} \mathrm{C}-33^{\circ} \mathrm{C}$ \\
\hline Salinity & $28-33 \mathrm{ppt}$ \\
\hline $\mathrm{pH}$ & $7.5-8.2$ \\
\hline Water transparency & $25-100 \%$ \\
\hline DO level & $6-8 \mathrm{ppm}$ \\
\hline
\end{tabular}

According to the study by Harith et al. (2018), sea cucumbers population in Satang Besar Island, Sarawak, Malaysia able to survive at water temperature of $27.2^{\circ} \mathrm{C}$ to $40.8^{\circ} \mathrm{C}$. However, the optimum water temperature for sea cucumber (Holothuria leucospilota) to spawn and other physiological performances is $5^{\circ} \mathrm{C}$ to $15^{\circ} \mathrm{C}$ because sea cucumbers preferably in colder region (FAO, 2008). Yet, the optimum water temperature is dependent of the species of sea cucumbers and region. Other than that, the salinity for $H$. leucospilota survival ranged from 27 to 35 ppt and proved that these ranges are favorable for sea cucumber as the ANOVA statistical analysis showed significant differences in salinity values of all sampling sites ( $p<$ 0.05) (Ceesay, Shamsudin and Alipiah, 2011). For $\mathrm{pH}$ value, the results showed ranged from 8.47 to 9.47 of all sampling sites and the statistical analysis results showed significant differences in all stations as $p$ value is less than 0.05. This indicated the water $\mathrm{pH}$ was still favorable for survival of $\mathrm{H}$. leucospilota in Satang Besar Island. Favorable environmental condition for survival of sea cucumbers allow them to perform their ecological roles. This indirectly indicated that the environment was in good health 2020 November Edition | www.jbino.com | Innovative Association 
conditions without environmental stressors and pollutants that affects the sea cucumbers.

A study by Sembiring et al. (2019) stated that the range of water temperature for sea cucumber were $26.7^{\circ} \mathrm{C}$ to $30.2^{\circ} \mathrm{C}$ with DO level of 6.62 to 6.78 ppm. Meanwhile, some sea cucumbers can survive at natural water temperature of $29^{\circ} \mathrm{C}$ to $33^{\circ} \mathrm{C}$ with DO level of 6.7 to $7.9 \mathrm{ppm}, 28$ to 33 salinity and 25 to $100 \%$ water transparency (Andriyono et al., 2016). Water temperature above $25^{\circ} \mathrm{C}$ or below optimum range could results in poor metabolism rate, affecting respiratory, feeding and other physical voluntary activities (Gunay et al., 2015; Hu et al., 2010). This phenomenon causes environmental stresses to sea cucumbers which results inactive in feeding, liquid secretion, skin color changes and severely evisceration that inject whole digestive system out of the body when they under stress conditions. Based on study by Lavitra et al., (2010), the ideal salinity for survival of sea cucumber is in the range of 28 to 31 ppt. A sudden change of salinity can cause serious impacts on their survival, growth as well as immunity and metabolism rates which eventually can cause death.

Sea cucumbers play their responsibilities in cleaning the seabed, nutrient recycling and bioturbation. They are able to reduce the organic waste produced in the aquatic ecosystem indirectly rebalanced the water quality and health condition of the environment. sea cucumber can also balance the water $\mathrm{pH}$ preventing ocean acidification through feeding and excretion. They ingest organic loads that reduced the water $\mathrm{pH}$ and increase the alkalinity by excretion of inorganic nitrogen and phosphorus which supplied food sources to other aquatic organisms. Without sea cucumber, it is likely to decline the ecosystem health by reducing nutrient cycle, downgrade sediment health and increase organic loads in the seabed (Purcell, Conand, Uthicke and Byrne, 2016). IOgoren-Emiroglu and Gunay (2007) reported that sea cucumbers reduced the concentration of ammonium level and organic wastes by consuming the organic loads present within the sediments in the aquarium. The water $\mathrm{pH}$ was higher in the aquarium with sea cucumber than that of control (without sea cucumber) as this may be due by the feeding and excretion of sea cucumbers that increase the water alkalinity from the acidic water caused by organic loads. Capability in rising water alkalinity proved that sea cucumber can act as buffer to increase water $\mathrm{pH}$ from acidic water resulted from excessive carbon dioxide emission or organic wastes from environment leading to ocean acidification.

Besides, an aerobic environment formed with the feeding and bioturbation activities of sea cucumber resulting oxygenation of the sediment. Accumulation of organic wastes in the sediment disturbs the environment and depletes DO level in the sediment can result in anoxic condition in the sediment. In an anoxic condition, insoluble Fe-P complexes can be reduced to soluble $\mathrm{Fe}$ (II) which facilitates release of phosphorus that can cause eutrophication (Hou et al., 2018; Alcaraz, 2018). With the bioturbation of sea cucumbers, accumulation of organic 2020 November Edition | www.jbino.com | Innovative Association 
wastes in the aerobic condition sediment can be prevented and enhance nutrients exchange as well as organic matter decomposition (MacTavish, StentonDozey, Vopel and Savage, 2012; Steven et al., 2017; Hou et al., 2017). This proved that sea cucumbers have the potential as ocean cleaners in monitoring water quality and health status of aquatic ecosystems.

\section{Buffering Coral reefs against Ocean Acidification}

On the other hand, sea cucumber could play its role in preserving coral reefs ecosystem from bleaching due to ocean acidification. This is because one of the aquatic organisms that inhabit in reef ecosystems is echinoderms (Mulyono et al., 2017). Coral reefs required calcium carbonate $\left(\mathrm{CaCO}_{3}\right)$ to build the reef skeletons in order to protect the reef organisms and provide a substrate to be attached by new polyps (Lam et al., 2019). During these processes, high amount of energy obtained from zooxanthellae which are photosynthetic algae that lives in coral's tissue providing energy to coral from photosynthesis so that coral can use to produce $\mathrm{CaCO}_{3}$. In return, coral provided protection and food sources that zooxanthellae needed for photosynthesis. This mutualistic relationship improved nutrient recycling in the insufficient nutrient condition. However, climate change induces ocean acidification with increasing of carbon dioxide that dissolved in the water and reduced the water $\mathrm{pH}$. This phenomenon resulting in coral bleaching where the zooxanthellae expel from the corals and turn white. It was believed that sea cucumber came up as an alternative to reduce harmful impacts of ocean acidification on coral growth and mitigate local climate change impacts.

Sea cucumbers have simple digestive system that starts with mouth to the stomach which broken down ingested particles into essential nutrients sent to the intestine and pass through the anus. However, this digestion of sea cucumber plays important role in reduction of water acidity and production of $\mathrm{CaCO}_{3}$. According to research by Schneider et al. (2011), they investigated the potential of sea cucumbers on maintaining water $\mathrm{pH}$ in reef ecosystems. Ingestion and feeding of sediments by sea cucumbers enhanced the natural digestive tract in the guts by broken down ingested benthic sands and particulate matters can indirectly elevate water $\mathrm{pH}$ when they defecated (Buccheri et al., 2019; O'Hara and Byrne, 2017). The by-products of defecation include $\mathrm{CaCO}_{3}$ and ammonia wastes which are the key component providing essential nutrients for building reefs skeletons as well as nutrients for coral growth. These byproducts can also increase the water alkalinity and reduce $\mathrm{CaCO}_{3}$ dissolution to counter the impacts of ocean acidification (Vidal Ramirez, 2017; Purcell, Conand, Uthicke and Byrne, 2016). During ocean acidification, coral reefs required more $\mathrm{CaCO}_{3}$ at higher rate compared to normal condition to overcome the bleaching. Hence, sea cucumber as keystone species in reef ecosystems play vital roles in maintaining good health condition of coral reefs and other calcifying organisms through its natural digestion processes providing $\mathrm{CaCO}_{3}$ as by-products. 


\section{Preliminary study}

In present study, an optimum water condition was established for sea cucumbers' survival in an aquarium. The preliminary study was conducted to assess physiochemical water quality parameters of sea cucumber as marine bioindicator. Their behavior and morphology were monitored so that abnormal condition of sea cucumber can be easily detected when environment stresses occur. Based on the results, water quality in the aquarium for sea cucumber was maintained as natural condition of marine water. Water temperature was between $26.1^{\circ} \mathrm{C}$ to $26.8^{\circ} \mathrm{C}$ which was in the range of $22^{\circ} \mathrm{C}$ to $32^{\circ} \mathrm{C}$ for survival of sea cucumber (Figure 4). Water is aerated and maintained above $5 \mathrm{mg} / \mathrm{L}$. The DO level was ranged from 7.7 to $8.2 \mathrm{mg} / \mathrm{L}$ in the tank (Figure 5). Higher DO level holds more diverse invertebrates and their activities. The salinity was 29 to 30 ppt which was in the ideal range of 29 to 34 ppt for sea cucumber to live (Figure 6). Behaviors showed normal where the sea cucumber was fully exposed, normal feeding with its tube feet and no evisceration occur. The established marine environment was ideal for sustaining the living of sea cucumber as all the water quality parameters were in the preferable range for sea cucumber in natural aquatic ecosystems.

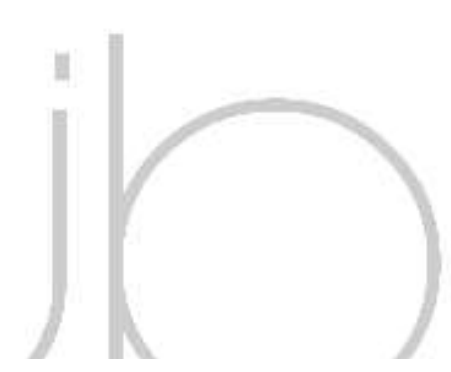

WATER TEMPERATURE
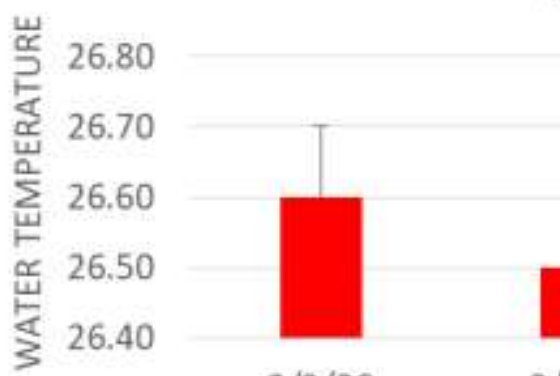

$2 / 3 / 20$

$2 / 4 / 20$
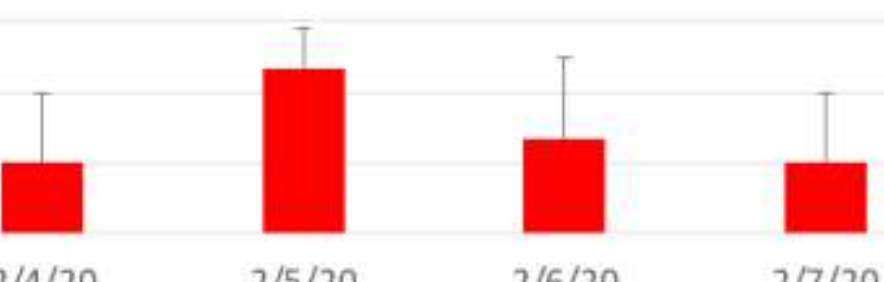

Figure 4: Water temperature for sea cucumber in a week. 
DO LEVEL

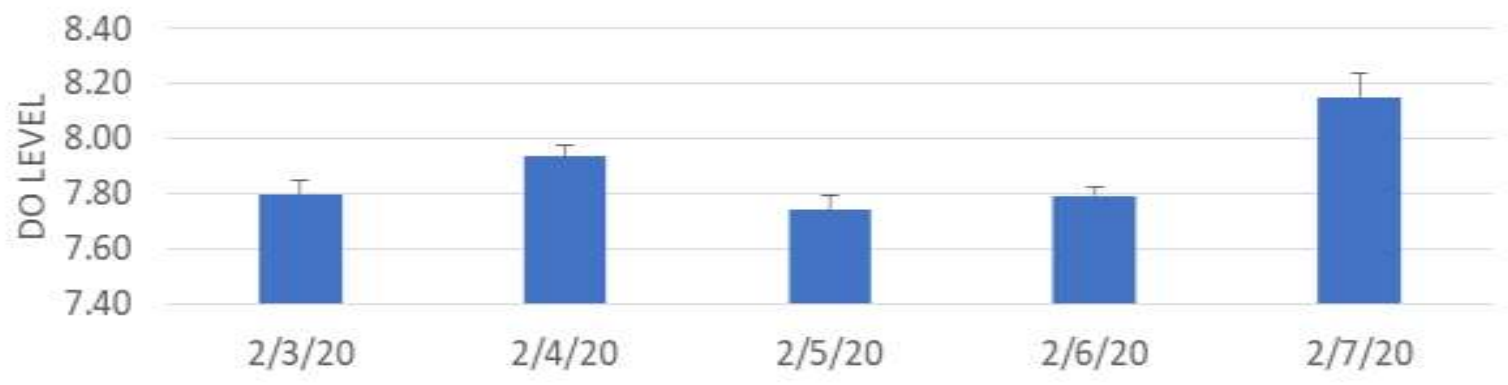

Figure 5: DO level for sea cucumber in a week.

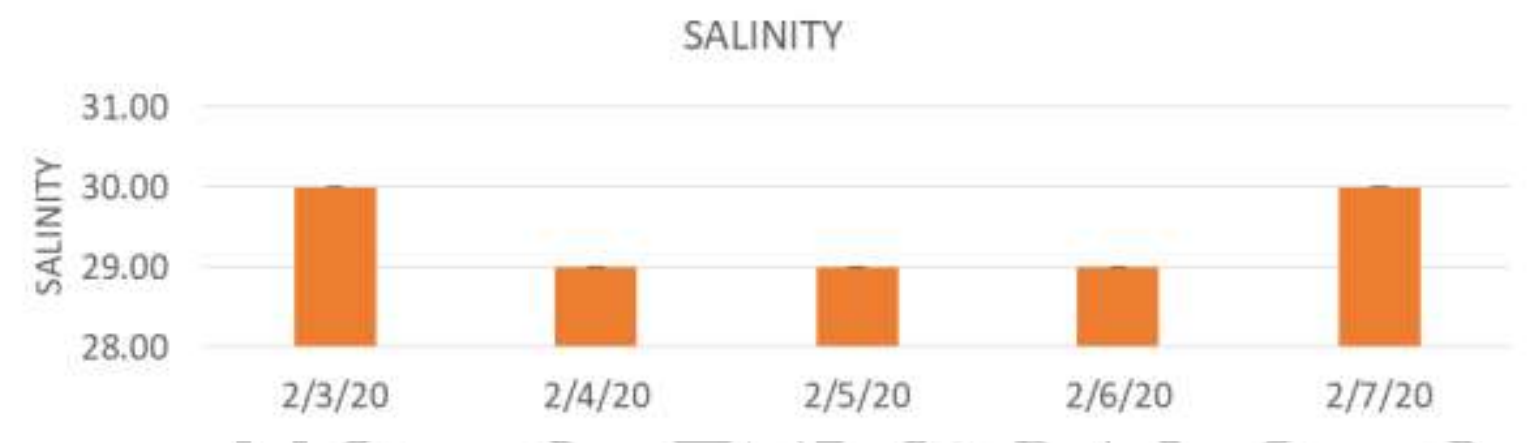

Figure 6: Salinity of water for sea cucumber in a week.

\section{Conclusion}

In aquatic environment monitoring, sea cucumbers suggested to be the ideal marine bioindicators in assessing pollution agents and environment water quality. They were able to survive in the water conditions conducted in the preliminary study and the physiochemical parameters were stable in the optimum range suggested in the natural aquatic ecosystems. Capability of sea cucumbers as marine bioindicators for heavy metal accumulation and reduce organic loads as well as excessive nutrients in the water environment that can cause marine pollutions had been proven in previous researches. They also had the ability to reduce harmful impacts from ocean acidification in the coral reef ecosystem by serve as buffer to balance or increase water alkalinity. Hence, performance of sea cucumbers as marine bioindicators will be examined and investigated in further study by histology examination and toxicology test of body compartments in pattern of heavy metals analysis as well as water quality testing.

\section{References}

1. Ahmed, Q., Mohammad Ali, Q. and Bat, L., 2017. Assessment of heavy metals concentration in holothurians, sediments and water samples from coastal areas of Pakistan (Northern Arabian Sea). 
Journal of Coastal Life Medicine, 5(5), pp.191-201.

2. Alcaraz, A.S., 2018. Bioturbation and Efficiency of Sediment Ingestion Of The Black Sea Cucumber Holothuria Atra Based On Sediment Size.

3. A Majid, N., Ramli, N. and Chia Phang, I., 2015. Pelargonium Radula As A Plant Bioindicator In Monitoring Mercury In Drinking Water. Jurnal Teknologi, 77(24).

4. Andriyono, S., Masithah, E., Rumiyati, B., JuniTriastuti and Winarni, D., 2016. The Behavior of Sea Cucumber Phyllophorus sp. during the Period of Adaptation. Asian Journal of Applied Sciences, 4(4).

5. Augustyn, A., Bauer, P., Duignan, B., Eldridge, A., Gregersen, E., McKenna, A., Petruzzello, M., Rafferty, J., Ray, M., Rogers, K., Tikkanen, A., Wallenfeldt, J., Zeidan, A. and Zelazko, A., 2020. Pelagic zone. In: Encyclopaedia Britannica. Encyclopaedia Britannica, inc.

6. Barakat, M., 2011. New trends in removing heavy metals from industrial wastewater. Arabian Journal of Chemistry, 4(4), pp.361377.

7. Buccheri, E., Foellmer, M., Christensen, B., Langis, P., Ritter, S., Wolf, E. and Freeman, A., 2019. Variation in Righting Times of Holothuria atra, Stichopus chloronotus, and Holothuria edulis in Response to Increased Seawater Temperatures on Heron Reef in the Southern GBR. Journal of Marine Biology, 2019, pp.1-6.

8. Ceesay, A., Shamsudin, M. and Alipiah, N., 2011. Biodiversity and Adaptability of Holothuria leucospilota and Stichopus japonicus Sea Cucumber Species in Artificial Environment. Journal of Aquaculture Research \& Development, 03(02).

9. Chovanec, A., Hofer, R. and Schiemer, F., 2003. Chapter 18 Fish as bioindicators. Bioindicators \& Biomonitors - Principles, Concepts and Applications, pp.639-676.

10. Dadolahi-Sohrab, A., Nikvarz, A., Nabavi, S., Safahieh, A. and Mohseni, M., 2011. Environmental Monitoring of Heavy Metals in Seaweed and Associated Sediment from the Strait of Hormuz, I.R. Iran. World Journal of Fish and Marine Sciences, 3(6), pp.576-589.

11.Dong, Y., Dong, S., Tian, X., Zhang, M. and Wang, F., 2005. Effects of water temperature on growth, respiration and body composition of young sea cucumber Apostichopus japonicus. Journal of Fishery Sciences of China, 12, pp.33-38.

12.FAO, Brief introduction to mariculture of five selected species in

China, 2008 , http://www.fao.org/docrep/field/0 03/AB736E/AB736E00.htm. 
13. Gasim, H., Hashim, A., Bakri, P., Samsuri, M., Rais, N. and Noor, N., 2013. Marine Pollution at Northeast of Penang Island. Research Journal of Applied Sciences, Engineering and Technology, 6(8), pp.1348-1353.

14. Gresens, S., Smith, R., Sutton-Grier, A. and Kenney, M., 2009. Benthic macroinvertebrates as indicators of water quality: The intersection of science and policy. Terrestrial Arthropod Reviews, 2(2), pp.99-128.

15. Gunay, D., Emiroglu, D., Tolon, T., Ozden, O. and Saygi, H., 2015. Growth and Survival Rate of Juvenile Sea Cucumbers (Holothuria tubulosa, Gmelin, 1788) at Various Temperatures. Turkish Journal of Fisheries and Aquatic Sciences, 15(2), pp.533-541.

16. Harith, M., Md Desa, M. and llias, Z., 2018. Holothuria leucospilota Population in Satang Besar Island, Sarawak, Malaysia. International Journal of Zoology, pp.1-6.

17. Holt, E.A. and Miller, S.W., 2010. Bioindicators: Using Organisms to Measure Environmental Impacts. Nature Education Knowledge, 3(10), pp. 8.

18. Hou, Y., Sun, Y., Gao, Q., Dong, S., Wen, B. and $Y u, H ., 2017$. Effect of the bioturbation derived from sea cucumber Apostichopus japonicus (Selenka) farming on the different occurrence forms of sedimentary inorganic carbon. Aquaculture, 480, pp.108-115.
19. Hou, Y., Sun, Y., Gao, Q., Dong, S., Wen, B., Pan, Z. and Liu, C., 2018. Bioturbation by sea cucumbers Apostichopus japonicus affects sediment phosphorus forms and sorption

characteristics. Aquaculture Environment Interactions, 10, pp.201-211.

20.Hu, C.J., Xu, Y.H., Wen, J., Zhang, L.P., Fan, S.G., and SU, T., 2010. Larval development and juvenile growth of the sea cucumber Stichopus sp. (Curry fish). Aquaculture, 300(1):73-79.

21.Hu, H., 2000. Exposure To Metals. Primary Care: Clinics in Office Practice, 27(4), pp.983-996.

22. Hu M., Li Q., Li L., 2010. Effect of salinity and temperature on salinity tolerance of the sea cucumber Apostichopus japonicus. Fish Sci 76 : 267-273.

23. IOgoren-Emiroglu, D. and Gunay, D., 2007. The Effect of Sea Cucumber Holothuria tubulosa (G., 1788) onNutrient and Sediment of Aegean Sea Shores. Pakistan Journal of Biological Sciences, 10(4), pp.586-589.

24. Jinadasa, B.K.K.K., Samanthi, R.I., and Wicramsinghe, I., 2014. Trace Metal Accumulation in Tissue of Sea Cucumber Species; NorthWestern Sea of Sri Lanka. American. Journal of Public Health Research, 2(5A), pp.1-5. 
25. Kingsford, M., 2018. Marine ecosystem. In: Encyclopaedia Britannica, 1st ed. Encyclopaedia Britannica, inc.

26. Lam, V., Chavanich, S., Djoundourian, S., Dupont, S., Gaill, F., Holzer, G., Isensee, K., Katua, S., Mars, F., Metian, M. and HallSpencer, J., 2019. Dealing with the effects of ocean acidification on coral reefs in the Indian Ocean and Asia. Regional Studies in Marine Science, 28, p.100560.

27. Lavitra L., Fohy N., Gestin P.G, Rasolofonirina R., Eeckhaut I., 2010. Effect of water temperature on the survival and growth of endobenthic Holothuria scabra (Echinodermata:Holothuroidea) juveniles reared in outdoor ponds. SPC Beche-de-mer information Bulletin 30: 25-26.

28. Li, L., Tian, X., YU, X. and Dong, S., 2016. Effects of Acute and Chronic Heavy Metal (Cu, Cd, and Zn) Exposure on Sea Cucumbers (Apostichopus japonicus). BioMed Research International, 2016, pp.113.

29. Lin, S., Chen, L., Jia, Y., Xiao, H., Xue, Y. and Zheng, Y., 2018. Distribution and Chemoenzymatic Removal of Heavy Metals in Sea Cucumber (Acaudina leucoprocta). Food Science and Technology Research, 24(2), pp.223-229.

30. MacTavish, T., Stenton-Dozey, J., Vopel, K. and Savage, C., 2012. Deposit-Feeding Sea Cucumbers 2020 November Edition | www.jbino.com | Innovative Association
Enhance Mineralization and Nutrient Cycling in OrganicallyEnriched Coastal Sediments. PLOS ONE, 7(11), p.e50031.

31. Manickavasagam, S., Sudhan, C., Bharathi and Aanand, S., 2019. Bioindicators in Aquatic Environment and their Significance. Journal of Aquaculture in the Tropics, 34(1), pp.73-79.

32. Mariné Oliveira, G., do Couto, M., de Freitas Lima, M. and do Bomfim, T., 2016. Mussels (Perna perna) as bioindicator of environmental contamination by Cryptosporidium species with zoonotic potential. International Journal for Parasitology: Parasites and Wildlife, 5(1), pp.28-33.

33. Mohamed, M.E and Aml, Z.G., 2017. The Antioxidant defense Responses of Sea cucumber Holothuria polii Against Rickettsia-like organism (RLOs) Infection and Heavy Metal Pollution in Alexandria coast. Journal of Bioscience and Applied Research, 3(3), pp..80-94.

34. Mohammadizadeh, M., Bastami, K., Ehsanpour, M., Afkhami, M., Mohammadizadeh, F. and Esmaeilzadeh, M., 2016. Heavy metal accumulation in tissues of two sea cucumbers, Holothuria leucospilota and Holothuria scabra in the northern part of Qeshm Island, Persian Gulf. Marine Pollution Bulletin, 103(1-2), pp.354-359. 
35. Mulyono, M., Apriandeni, N., Nurbani, S., Waluyo, A. and Hidayat, T., 2017. Community structure of sea cucumber on coral reefs in Togean Islands national parkcentral Sulawesi,Indonesia. International Journal of Fisheries and Aquatic Studies, 5(6), pp.201-204.

36. Naigaga, I., Kaiser, H., Muller, W., Ojok, L., Mbabazi, D., Magezi, G. and Muhumuza, E., 2011. Fish as bioindicators in aquatic environmental pollution assessment: A case study in Lake Victoria wetlands, Uganda. Physics and Chemistry of the Earth, Parts $A / B / C$, 36(14-15), pp.918-928.

37. Nouchi, I., 2002. Plants as Bioindicators of Air Pollutants. Air Pollution and Plant Biotechnology, pp.41-60.

38. O'Hara, T. and Byrne, M., 2017. Australian Echinoderms: Biology, Ecology And Evolution. Clayton, Australia: CSIOR Publishing, pp.102-104.

39.Parmar, T., Rawtani, D. and Agrawal, Y., 2016. Bioindicators: the natural indicator of environmental pollution. Frontiers in Life Science, 9(2), pp.110-118.

40. Patrick, M., Mbuebue, T. and Nadine, M., 2015. Benthic macroinvertebrates as indicators of water quality: a case-study of urban Funa Stream (in Kinshasa, Democratic Republic of Congo). Open Journal of Water
Pollution and Treatment, 2015(1), pp.8-24.

41.Pawhestria, S., Hidaya, J. and Putro, S., 2015. Assessment of Water Quality Using Macrobenthos as Bioindicator and Its Application on Abundance-Biomass Comparison $(A B C)$ Curves. International Journal of Science and Engineering, 8(2), pp.84-87.

42.Purcell, S., Conand, C., Uthicke, S. and Byrne, M., 2016. Ecological Roles of Exploited Sea Cucumbers. Oceanography and Marine Biology - An Annual Review, 54, pp.367-386.

43.Schneider, K., Silverman, J., Woolsey, E., Eriksson, H., Byrne, M. and Caldeira, K., 2011. Potential influence of sea cucumbers on coral reef $\mathrm{CaCO}_{3}$ budget: $\mathrm{A}$ case study at One Tree Reef. Journal of Geophysical Research, 116(G4).

44. Sembiring, S., Wibawa, G., Hutapea, J. and Adiasmar, I., 2019. The Effect Of Salinity On Survival, Growth And Immunity Rate Of Sea Cucumber (Holothuria Scabra) Juveniles. Biotropia, 26(3).

45.Stankovic, S. and Stankovic, A., 2013. Bioindicators of Toxic Metals. Environmental Chemistry for a Sustainable World, pp.151-228.

46. Steven, L., Ferse, S., Ford, A., Wild, C. and Mangubhai, S., 2017. Effect of sea cucumber density on the health of reef-flat sediments. In S. Mangubhai, W. Lalavanua and S.W. Purcell (eds.). Fiji's Sea Cucumber 
Fishery: Advances in Science for Improved Management. Wildlife Conservation Society. Report No. 01/17. Suva, Fiji. pp. 54-61

47. Tchounwou, P., Yedjou, C., Patlolla, A. and Sutton, D., 2012. Heavy Metal Toxicity and the Environment. Experientia Supplementum, pp.133164.

48. Vallaeys, T., 2017. Bioindicators of Marine Contaminations at the Frontier of Environmental Monitoring and Environmental Genomics. Advances in Biotechnology \& Microbiology, 4(1).
49. Vidal Ramirez, F., 2017. Effects of past, present and possible future seawater environments on sea cucumbers and the sediments they process. PhD Thesis, School of Biological Sciences, The University of Queensland

50. Yang, H., Yuan, X., Zhou, Y., Mao, Y., Zhang, T. and Liv, Y., 2005. Effects of body size and water temperature on food consumption and growth in the sea cucumber Apostichopus japonicus (Selenka) with special reference to aestivation. Aquaculture Research, 36(11), pp.1085-1092. 